\title{
Emotional Intelligence, Perceived Social Support and Mental Health of Institutionalized Elderly
}

\author{
${ }^{1}$ Zebeda Abd El Gawad Elsherif, ${ }^{2}$ Suzan Abd elmonem Abd Elgafaar, \\ ${ }^{1}$ Assistant Prof. of Mental Health and Psychiatric Nursing. Faculty of Nursing, Tanta \\ University Egypt. \\ ${ }^{2}$ Lecturer of Mental Health and Psychiatric Nursing. Faculty of Nursing, Tanta University, \\ Egypt \\ Z.alsherif@gmail.com \\ souzanabdelmenem@yahoo.com
}

\begin{abstract}
Many life circumstances such as physical health, income and social support, may decline in later adulthood, older adults who are higher in emotional intelligence may adjust their life goals and use more effective emotion regulation strategies, such as cognitive reappraisal, to enhance their life and their affective well-being. The objective of this study was to determine the relationship between the emotional intelligence, social support and mental health of institutionalized elderly. Design: A correlational descriptive design was used. Setting: The study was conducted at Dar- El Saada geriatric home in Tanta city.
\end{abstract} Subjects: selected only 54 older adults who were passed by cognitive impairment test. Three tools used for this study: tool I: Emotional intelligence scale, tool II: Multidimensional perceived social support, tool III: General Health Questionnaire 28 item. Result: The results of this study showed that the majority of the studied subjects had low emotional intelligence. And there was low percentage of subjects $(83.3 \%)$ had low social support levels. Also it was found that two thirds of the studied subjects had poorer mental health. Conclusions: The results concluded that there was a significant positive relation between emotional intelligence and social support. The study also found negative relation between emotional intelligence and poor mental health, also the study found a significant negative relation between mental health of elderly and their level of perceived social support. Recommendation: Future researches are needed to find out exactly how older adults with higher emotional intelligence cope with the changing life circumstances to maximize their well-being.

Key words: Emotional intelligence, Elderly, Metal health, Social support. 


\section{Introduction}

One of the main features of the Egyptian population over the last few decades is the gradual increase in the absolute and relative numbers of older people ${ }^{(1)}$. The Egyptian census is carried out every 10 years, the percent of older people "defined as 60 years of age and more" was $6.27 \%$ in 2006, 8.9\% in 2016 and expecting the figure rising to 10.9 in $2026^{(2)}$. with regard to the fact that the elderly's mental and physical abilities reduces due to senility, various diseases and mental problems that threaten their health make the elderly's health is of particular importance. Therefore, increasing elderly population is one of the most important economic, social, and health challenges in the present century ${ }^{(3)}$.

Mental health is one of the important aspects requiring special attention to prevent mental disorders such as depression and anxiety moreover, mental health has a big impact on physical health, (for example, coexisting depression in people with diabetes is associated with decreased adherence to treatment, higher complication rates, decreased quality of life, increased disability and increased risk of death). Conversely, people with medical conditions such as heart disease, diabetes, asthma and arthritis have higher rates of depression than those who are medically well $^{(4,5)}$.

Various studies indicated that greater vulnerability to mental disorders has been observed in those who are institutionalized which make it essential to investigate the factors that determine the mental health of that population ${ }^{(6,7)}$. Mental health can be affected by many factors such as poverty, social isolation, loss of independence, and loneliness. Older adults are more likely to experience events such as sadness or physical disability that affect emotional well-being and can result in poorer mental health. They may also be exposed to abuse at home and in care institutions ${ }^{(8-10)}$. On the other side, it is necessary to identify factors that can promote and have a positive impact on the wellbeing of this group. Among these factors, the construct of emotional intelligence are likely to have a protective role in the mental health outcomes of this population ${ }^{(11)}$, and can predict an individual's greater psychological adjustment ${ }^{(12)}$. Emotion is somewhat unaffected by aging or even enhanced with age, in comparing to most cognitive functions ${ }^{(13)}$. Aging is connected with improved emotional problem solving and increased frequency of positive feelings ${ }^{(14)}$. 
Emotional intelligence (EI) is a generic ability in perceiving emotions both in one and in others. This ability helps the individual to regulate his emotions and cope effectively with emotive situations ${ }^{(15)}$. It is defined as "the ability to monitor one's own and others' feelings and emotions, to distinguish among them, and to use this information to guide one's thinking and action" (16). Emotional intelligence (EI) is made up of four key emotional abilities: accurate perception, appraisal, and expression of emotions; access to and/or generation of feelings that facilitate thought; understanding of emotions and generation of emotional knowledge; and regulation of emotions by improving emotional and intellectual growth ${ }^{(17)}$.

Generally, emotional intelligence play an effective role in detecting appropriate emotional responses in the face of everyday events, broadening the vision, and creating a positive attitude towards events and emotions. Healthier Individuals who accurately perceive and appraise their emotional states can effectively regulate their emotional states, know how and when to express their feelings .These characteristics, can deal with the perception, expression, and regulation of moods and emotions, suggests that there is a direct connection between emotional intelligence and physical as well as mental health $^{(18,19)}$.

Compared to secure persons, insecure individuals are found to be less adjusted on measures of well-being including loneliness, depression, anxiety, hostility and psychosomatic illness. Insecure attachment has been consistently associated with low levels of emotional well-being and high levels of depression and anxiety ${ }^{(20)}$. Perceived social support has been found to be an important determinant for improving the Quality of Life of older people. Psychological wellbeing among older adults can be enhanced by social support. Instrumental support (e.g., affection, companionship, transportation, and nursing care, etc.) has been found to play a primary role in increasing older persons' self-esteem, competency, and autonomy. Especially, the support of family as well as friends can make an important contribution to older adults' well-being. These social networks can give older adults a sense of belonging $^{(21)}$.

Social support consist of interpersonal communication and interaction, love and understanding, caring and concern, affection and companionship, financial assistance, respect and acceptance. Many 
studies have confirmed the contributions of social supports to the life satisfaction of older people. People in different living arrangements also vary across indicators of social support. To the extent that particular types of living arrangements define these social conditions, it is important to understand how they influence life satisfaction $^{(22)}$.

The most frequent cause of emotional suffering is a late-life depression and is also found to be a risk for poor self-rated health over time. The prevalence of psychological distress increased by decreasing social status. The negative effect of somatic health problems on social support implies that social support may be a moderator in the relationship between somatic disorders and psychological distress. Because somatic health problems tend to reduce social support, which is a risk factor for mental health problems, somatic health problems increase the risk of mental health problems ${ }^{(23)}$.

Having a high level of social support from multiple sources (e.g., family, friends, significant other) allow individuals to reappraise the unlikable situations, share their upsetting emotions, and seek alternatives to cope, thereby enhance the possibly harmful impacts of negative events on mental health. Consequently, it is believable to assume that social support might lead to improved psychological well-being of individuals (24). Therefore this study was aimed to evaluate the effect of emotional intelligence on mental health of institutionalized elderly.

Aim of the study: The aim of the study was to determine the relationship between the emotional intelligence, perceived social support and mental health of institutionalized elderly.

\section{Research question:}

Is there a relation between the elderly emotional intelligence, perceived social support and their mental health?

\section{Subjects and methods;}

\section{Research Design:}

A descriptive correlation design was used for the current study.

\section{Setting:}

The study was conducted at Dar- El Saada geriatric home in Tanta city which contain about 50-60 older adults living in it. This setting serves El-Gharbia, el-menofia, and Khafr-Elsheik Governorate.

Subjects: 54 older adults participated in this study who have the following inclusion criteria:

- Selecting only participants who were passed by cognitive impairment test -Age 60 and above

-Willing to participate in the study 


\section{Exclusion criteria:}

-Cognitive impairment

-Drug addict

-Mentally retarded

\section{Data Collection Tools:}

Three tools were used to collect data for this research:

The Mini Mental State Examination (MMSE) ${ }^{(25)}$, it was used before embarking in the actual study to measure the cognitive function of the elderly to include in this study. And it was developed by Folstein MF, Folstein SE, McHugh PR. (1975), it consisted of 11-question measure that tests five areas of cognitive function: orientation, registration, attention and calculation, recall, and language. The maximum score is 30. A score of 23 or lower is indicative of cognitive impairment.

1-Emotional intelligence scale: it was developed by Schutte et al (1998), (26) It was used to evaluate emotional intelligence ( measuring a person's belief in his/her emotional ability) This scale includes 33 items divided into four subscales ; mood regulation (15) items, emotional appraisal (8 items ), emotional utilization (5) items, and social skills (5) items, there are 5 responses for each question ranging from strongly disagree (1) to strongly agree (5). In the study the
Likert scoring procedure (5, 4, 3, 2, and 1) for reversed questions $(5,28,33)$ the scoring is reversed and the total scale score ranges from 33-165

The score ranged from 33 to 165 , with the higher scores indicating more characteristic emotional intelligence. The mean emotional intelligence score is 124 ; higher scores indicate higher levels of emotional intelligence:

Scores below 111 indicate low level of emotional intelligence or above 137 are considered higher levels of emotional intelligence.

2-Multidimensional perceived social support scale (MSPSS), (27 ) It was developed by (Zimet, Dahlem, Zimet and Farley, 1988) and designed to measure perceptions of support from 3 sources: Family, Friends, and Significant other. The scale is comprised a total of 12 items, with 4 items for each subscale, there are 7 responses for each question ranging from very strongly disagree (1) to very strongly agree (7)

\section{Scoring system:}

The minimum and maximum score that can be acquired from each total score is 12 and 84 respectively, and 4 and 28 respectively for each subscale. A total score of $12-48$ is taken as poor perceived social support, 49-68 as moderate 
perceived social support and, 69-84 as high perceived social support.

\section{3-General Health Questionnaire 28}

items (GHQ). It was developed by

Goldberg and Hillier (1979), ${ }^{(28)}$ used

to diagnose brief -non psychotic disorders it consisted of 28 items classified into four subscales; somatic symptoms, anxiety and insomnia, social dysfunction, and severe depression, each subscale consisted of 7 items, there are 4 responses for each question ranging from (1) not at all, (2) no more than usual, (3) rather more than usual (4) much more than usual). In the study the Likert scoring procedure $(1,2,3$, and 4), the total scale score ranges from 28 to 112 .

The maximum score for each subscale in this questionnaire is 28. Any score is equal or more than 5 is deemed a positive case or affected.

The tools of the study supported by Interview Schedule Questionnaire contain socio-demographic characteristics of elderly which include: age, sex, marital status, residence, level of education, occupation, income, causes of admission, duration of admission.

\section{Methods:}

- Official permission to conduct the study was obtained from faculty of nursing to the responsible authorities to facilitate the researchers' work.

- Ethical consideration:

- Approval of the ethical committee was obtained before conducting the study.

- A written informed consent was taken from elderly to participate in the study after explanation of the purpose of the study.

- The participants were reassured about the confidentiality and privacy of the obtained information.

- Respecting the elderly rights to refuse to participation in the study and to withdraw at any time from the study.

- This study caused no harm for the subjects.

-The tool 1, 2, 3 was translated into the Arabic language by the researchers of the study.

- The tools were tested for its content validity by a jury composed of 5 experts in the field of psychiatric nursing, the expert panels were asked to evaluate the questions after translation according to readability, language appropriateness to avoid biases, and ease of understanding items. 
-A pilot study was carried out on $10 \%$ (8) older adults to ascertain the clarity, visibility, and applicability of the study tools and its translation, as well as to determine any obstacles that may be encountered during the time of data collection. Accordingly the necessary modifications were done and those older adults were excluded from the study subjects.

- Chronbach's Alpha coefficient of reliability of tool $\mathrm{I}$ is $0.70-0.85$

- Chronbach's Alpha coefficient of reliability of tool II, Overall internal consistency was excellent (Chronbach's Alpha $=.88$ )

- Chronbach's Alpha coefficient of reliability of the subscale of the tool III vary around 0.82 and the internal consistency of the total scale of the tool III is 0.92

\section{Data collection}

-The studied elderly were selected based on the inclusion criteria for participation in the study and according the Mini Mental State Examination.

-Tools of the study distributed on the subjects in an individual basis and the subjects were asked to fulfill the questionnaire in the presence of the researcher for any clarification, help and guidance.
-Each interview lasted for about 20-35 minute for fulfilling the three tools according to elderly attention and willingness.

-Data of the study were collected prospectively by the researchers over a period of 3 months starting from October 2017 and ended at December 2017

\section{Statistical analysis:}

- The collected data was organized, tabulated, coded and statistically analyzed using SPSS software statistical computer package version(25).

- Statistical presentation and analysis of the present study was conducted using, for quantitative data, the range, mean and standard deviation were calculated. For qualitative data, comparison was done using Chi-square test $\left(\chi^{2}\right)$. Correlation between variables was evaluated using Pearson and Spearman's correlation coefficient r. A significance was adopted at $\mathrm{P}<0.05$ for interpretation of results of tests of significance $(*)$. Also, a highly significance was adopted at $\mathrm{P}<0.01$ for interpretation of results of tests of significance $(* *)$.

\section{Results}


Table (1) Presents the distribution of the studied subjects according to their sociodemographic characteristics. As their age ranged between 60-77 years with a mean age of $66-20 \pm 4.676$ years. The results revealed that the highest percentage of the studied subjects $(37 \%)$ aged between 6065 , and $35.2 \%$ aged between 65-70 years and the lowest percentage of them $(3.7 \%)$ aged more than 75 years. It was also found that $51.9 \%$ of the studied subjects were female and $48.1 \%$ were widowed, and $33.3 \%$ of them were divorced. As for living residence $(72.2 \%)$ of patients were from urban areas and $(27.8 \%)$ of them were from rural area.

Concerning their educational level (38.9\%) of subjects had secondary school education, and only $11.1 \%$ of them were illiterate. Regarding their job $77.8 \%$ of the studied subjects were retired and only $22.2 \%$ do not work. It was found that $75.9 \%$ of the studied subjects said that their income was enough, and $44.4 \%$ of them were admitted the geriatric home for reason of loneliness. Also $63 \%$ of them had less than 5 years for duration of stay and $37 \%$ had 5 or more duration of stay in the geriatric home.

Table (2) Showed the total level of Schutte Self Report Emotional Intelligence Test (SSEIT). The results revealed that the high score of the subscale mood regulation loptimism was $55.6 \%$ and the range was 22-68 with a mean of $46.17 \pm 13.718$, indicating low level of emotional intelligence. High score of the subscale emotional appraisal was $48.1 \%$ and the range was 14-39 with a mean of 26.28 \pm 8.426 , indicating low level of emotional intelligence. Also high score of the subscale emotional utilization was $44.4 \%$ and the range was10-23 with a mean of 17.19 \pm 4.019 , indicating low level of emotional intelligence, and high score of the subscale social skills was $79.6 \%$ and the range was 8-26 with a mean of $17.13 \pm 4.674$, indicating low level of emotional intelligence. As total level of Self Report Emotional Intelligence was $70.4 \%$ of the studied subjects had low emotional intelligence.

Table (3) Revealed the percent distribution of the studied subjects regarding their total level of perceived social support. The results showed that low score of subscale significant others was $75.9 \%$ and the range was 4-23 with a mean of 11-13 \pm 6.069 , indicating low social support from significant others, and low score of subscale family was $92.6 \%$ and the range was 4-28 with a mean of 10-00 \pm 4.802 , indicating low social support from family. Also low score of subscale friends was 
$74.1 \%$ and the range was $4-25$ with a mean of 14-33 \pm 5.241 indicating low social support from friends, and the total score of perceived social support of subjects $(83.3 \%)$ had low social support levels.

Table (4) Presents the percent distribution of the studied subjects regarding their total level of General Health Questionnaire (GHQ). The results revealed that high score of subscale somatic symptoms was $61.1 \%$ and the range was $8-24$ with a mean of 17-26 \pm 4.443 , indicating high level of somatic symptoms, and high score of subscale anxiety and insomnia was $53.7 \%$ and the range was 8-26 with a mean of 17$74 \pm 6.559$, indicating high level of anxiety and insomnia. There was low level of social dysfunction (57.4\%) and the range was 9-25 with a mean of $19-80 \pm 4.877$, indicating low level of social dysfunctions. High score of severe depression was $61.1 \%$ and the range was 7-26 with a mean of 17$24 \pm 6.333$, indicating high level of severe depression .It was found that $(59.3 \%)$ of the studied subjects had low mental health.

Table (5) Presents the comparison and correlation between total level of Self Report Emotional Intelligence Test (SSEIT), total level of Perceived social support and total level of General Health Questionnaire (GHQ) among the studied subjects. The results revealed that there was a significant positive relation between emotional intelligence and the studied subjects' perceived social support at $\mathrm{r}=0.545, \mathrm{p}=0.00$. While there was a significant negative relation between emotional intelligence and the mental health of elderly at $\mathrm{r}=-0761, \mathrm{p}=0.00$.

Table (6) Illustrates the relation between the intelligence, social support, and the mental health of elderly (general health). As there was a significant negative relation between the mental health of elderly and the studied subjects' emotional intelligence at $\mathrm{r}=-0.761, \mathrm{p}=0.00$. And also there was a significant negative relation between the mental health of elderly and the studied subjects' level of perceived social support at $\mathrm{r}=-0.404, \mathrm{p}=0.002$.

Table (7) Clarifies the correlation between socio-demographic characteristics and total level of Schutte Self Report Emotional Intelligence Test (SSEIT), total level of Perceived social support and total level of General Health Questionnaire (GHQ) among the studied subjects. It was found a significant negative correlation between elderly age and their emotional intelligence at $\mathrm{r}=-0.440, \mathrm{p}=0.001$ and also a significant negative correlation between elderly age and their social support at $\mathrm{r}=0.310$, $\mathrm{p}=0.023$, but the present study found a significant positive correlation between 
elderly age and their mental health at $\mathrm{r}=0.399, \mathrm{p}=0.003$. As for gender it was found a significant positive correlation between female elderly and their mental health at $0.0439, \mathrm{p}=0.001$.

Regards marital status it was found a significant negative correlation between single elderly and their emotional intelligence at $\mathrm{r}=-0.490, \mathrm{p}=0.00$, and also had a negative one with their social support at $\mathrm{r}=-0.584, \mathrm{p}=0.00$, but it was found a significant positive correlation between single elderly and their mental health at $\mathrm{r}=0.282, \mathrm{p}=0.039$. There was a significant positive correlation between married elderly and their emotional intelligence at $\mathrm{r}=0.388, \mathrm{p}=0.004$, and had a negative one with their mental health at $\mathrm{r}=-0.401$, $\mathrm{p}=0.003$. There was a positive correlation between divorced elderly and their emotional intelligence at $\mathrm{r}=280, \mathrm{p}=0.004$, and had a negative one with their mental health at $\mathrm{r}=-0.330, \mathrm{p}=0.015$. There was a positive correlation between widow elderly with their mental health at $\mathrm{r}=0.344, \mathrm{p}=$ 0.011 .

In relation to educational level, there was a positive correlation between the study subjects' educational levels and their emotional intelligence, social support at $\mathrm{r}=0.562, \quad \mathrm{p}=0.00, \quad \mathrm{r}=0.378, \quad \mathrm{p}=0.005$ respectively, but there was a negative correlation between the study subjects' educational levels and their mental health at $\mathrm{r}=-0.577, \mathrm{p}=0.00$.

As regards elderly job, there was a positive correlation between the study subjects 'retirement and their emotional intelligence at $\mathrm{r}=0.399, \mathrm{p}=0.003$, and there was a positive correlation between the study subjects retirement and their social support at $\mathrm{r}=0.275, \mathrm{p}=0.044$, but a negative one between the study subjects retirement and their mental health at $\mathrm{r}=-0.424, \mathrm{p}=0.001$. It was found a negative correlation between the study subjects duration of stay in the geriatric home and their emotional intelligence at $\mathrm{r}=-0.327, \mathrm{p}=0.016$, and also with their perceived social support at $r=-$ $0.375, p=0.005$, but a positive one between the study subjects duration of stay in the geriatric home and their mental health at $\mathrm{r}=0.365, \mathrm{p}=0.007$. 
Table (1) : Distribution of the studied subjects according to their socio-demographic characteristics.

\begin{tabular}{|c|c|c|}
\hline \multirow[t]{2}{*}{ Socio-demographic Characteristics } & \multicolumn{2}{|c|}{$\begin{array}{c}\text { The studied elderly } \\
(\mathrm{n}=54)\end{array}$} \\
\hline & $\mathbf{N}$ & $\%$ \\
\hline $\begin{array}{l}\text { Age (in years) } \\
\text { : } 60<65 \\
\text { - } 65-<70 \\
\text {. } 70-<75 \\
\text { : } \geq 75\end{array}$ & $\begin{array}{c}20 \\
19 \\
13 \\
2\end{array}$ & $\begin{array}{c}37.0 \\
35.2 \\
24.1 \\
3.7\end{array}$ \\
\hline $\begin{array}{c}\text { Range } \\
\text { Mean } \pm \text { SD }\end{array}$ & \multicolumn{2}{|c|}{$\begin{array}{c}(60-77) \\
66.20 \pm 4.676\end{array}$} \\
\hline $\begin{array}{l}\text { Gender } \\
\text { - Male } \\
\text { - Female }\end{array}$ & $\begin{array}{l}26 \\
28 \\
\end{array}$ & $\begin{array}{l}48.1 \\
51.9\end{array}$ \\
\hline $\begin{array}{l}\text { Marital status } \\
\text { - Single } \\
\text { - Married } \\
\text { - Divorced } \\
\text { - Widow }\end{array}$ & $\begin{array}{c}6 \\
4 \\
18 \\
26\end{array}$ & $\begin{array}{c}11.1 \\
7.4 \\
33.3 \\
48.1\end{array}$ \\
\hline$\frac{\text { Residence }}{\text { - Urban }}$ & $\begin{array}{l}39 \\
15 \\
\end{array}$ & $\begin{array}{l}72.2 \\
27.8 \\
\end{array}$ \\
\hline $\begin{array}{l}\text { Educational level } \\
\text { : } \text { illiterate } \\
\text { : } \text { primary } \\
\text { : Secondary } \\
\text { University }\end{array}$ & $\begin{array}{c}6 \\
15 \\
21 \\
12\end{array}$ & $\begin{array}{l}11.1 \\
27.8 \\
38.9 \\
22.2\end{array}$ \\
\hline $\begin{aligned} & \underline{\text { Job }} \\
& \text { - } \text { Retired } \\
& \text { Don't work }\end{aligned}$ & $\begin{array}{l}42 \\
12\end{array}$ & $\begin{array}{l}77.8 \\
22.2\end{array}$ \\
\hline $\begin{array}{l}\text { Income } \\
\text { - Enough } \\
\text { - Not enough }\end{array}$ & $\begin{array}{l}41 \\
13\end{array}$ & $\begin{array}{l}75.9 \\
24.1\end{array}$ \\
\hline $\begin{array}{l}\text { Reason for admission } \\
\text {. Leaving home for son marriage } \\
\text { - Loneliness } \\
\text { - Hamily conflict } \\
\text { - His family desire } \\
\end{array}$ & $\begin{array}{c}10 \\
24 \\
14 \\
6\end{array}$ & $\begin{array}{l}18.5 \\
44.4 \\
25.9 \\
11.1 \\
\end{array}$ \\
\hline $\begin{array}{c}\text { Duration of stay (in years) } \\
:<5 \\
: \geq 5\end{array}$ & $\begin{array}{l}34 \\
20\end{array}$ & $\begin{array}{l}63.0 \\
37.0\end{array}$ \\
\hline $\begin{array}{c}\text { Range } \\
\text { Mean } \pm \text { SD }\end{array}$ & $\begin{array}{r}\mathbf{3 0 .} \\
\mathbf{3 . 7}\end{array}$ & \\
\hline
\end{tabular}


Table (2) Distribution of the studied subjects according to their total level of Schutte Self Report Emotional Intelligence Test (SSEIT).

\begin{tabular}{|c|c|c|}
\hline \multirow[t]{2}{*}{ Emotional Intelligence of elderly } & \multicolumn{2}{|c|}{$\begin{array}{c}\text { The studied elderly } \\
(n=54)\end{array}$} \\
\hline & $\mathbf{N}$ & $\%$ \\
\hline $\begin{array}{l}\text { Mood regulation/optimism } \\
\text { - }(14-46) \text { Low } \\
\text { - }(47-58) \text { Average } \\
\text { - }(59-70) \text { High }\end{array}$ & $\begin{array}{l}30 \\
14 \\
10\end{array}$ & $\begin{array}{l}55.6 \\
25.9 \\
18.5\end{array}$ \\
\hline 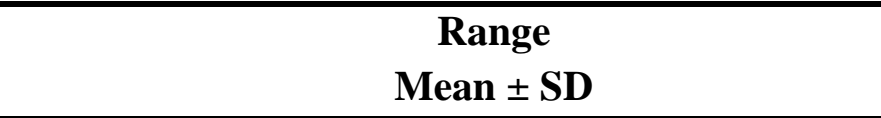 & \multicolumn{2}{|c|}{$\begin{array}{c}(22-68) \\
46.17 \pm 13.718\end{array}$} \\
\hline $\begin{array}{l}\text { Emotional appraisal } \\
\text { - }(8-26) \text { Low } \\
\text { - }(27-33) \text { Average } \\
\text { - }(34-40) \text { High }\end{array}$ & $\begin{array}{l}26 \\
13 \\
15\end{array}$ & $\begin{array}{l}48.1 \\
24.1 \\
27.8\end{array}$ \\
\hline 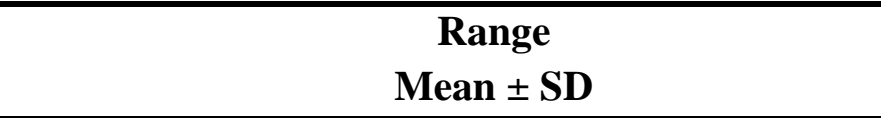 & \multicolumn{2}{|c|}{$\begin{array}{c}(14-39) \\
26.28 \pm 8.426\end{array}$} \\
\hline $\begin{array}{l}\text { Emotional utilization } \\
\text { - }(5-16) \text { Low } \\
\text { - }(17-21) \text { Average } \\
\text { - }(22-25) \text { High }\end{array}$ & $\begin{array}{l}24 \\
19 \\
11\end{array}$ & $\begin{array}{l}44.4 \\
35.2 \\
20.4\end{array}$ \\
\hline $\begin{array}{c}\text { Range } \\
\text { Mean } \pm \text { SD }\end{array}$ & \multicolumn{2}{|c|}{$\begin{array}{c}(10-23) \\
17.19 \pm 4.019\end{array}$} \\
\hline $\begin{array}{l}\text { Social skills } \\
\text { - }(6-20) \text { Low } \\
\text { - }(21-25) \text { Average } \\
\text { - }(26-30) \text { High }\end{array}$ & $\begin{array}{c}43 \\
8 \\
3\end{array}$ & $\begin{array}{c}79.6 \\
14.8 \\
5.6\end{array}$ \\
\hline $\begin{array}{c}\text { Range } \\
\text { Mean } \pm \text { SD }\end{array}$ & \multicolumn{2}{|c|}{$\begin{array}{c}(8-26) \\
17.13 \pm 4.674\end{array}$} \\
\hline $\begin{array}{l}\text { Total Schutte Self Report Emotional Intelligence } \\
\text { - }<111 \text { Low } \\
\text { - }(111-137) \text { Moderate } \\
\text { - }>137 \text { High }\end{array}$ & $\begin{array}{c}38 \\
4 \\
12\end{array}$ & $\begin{array}{c}70.4 \\
7.4 \\
22.2\end{array}$ \\
\hline $\begin{array}{c}\text { Range } \\
\text { Mean } \pm \text { SD }\end{array}$ & \multicolumn{2}{|c|}{$\begin{array}{c}(56-156) \\
106.76 \pm 27.249\end{array}$} \\
\hline
\end{tabular}


Table (3) : Percent distribution of the studied subjects regarding their total level of Perceived Social Support.

\begin{tabular}{|c|c|c|}
\hline \multirow[t]{2}{*}{ Types of Perceived Social Support by the level } & \multicolumn{2}{|c|}{$\begin{array}{l}\text { The studied elderly } \\
\qquad(\mathrm{n}=54)\end{array}$} \\
\hline & $\mathbf{N}$ & $\%$ \\
\hline $\begin{array}{l}\text { Form significant others } \\
\text { - }(4-16) \text { Low } \\
\text { - }(17-22) \text { Average } \\
\text { - }(23-28) \text { High }\end{array}$ & $\begin{array}{c}41 \\
10 \\
3\end{array}$ & $\begin{array}{c}75.9 \\
18.5 \\
5.6\end{array}$ \\
\hline $\begin{array}{c}\text { Range } \\
\text { Mean } \pm \text { SD }\end{array}$ & \multicolumn{2}{|c|}{$\begin{array}{c}(4-23) \\
11.13 \pm 6.069\end{array}$} \\
\hline $\begin{array}{l}\text { From family } \\
\text { - }(4-16) \text { Low } \\
\text { - }(17-22) \text { Average } \\
\text { - }(23-28) \text { High }\end{array}$ & $\begin{array}{c}50 \\
3 \\
1\end{array}$ & $\begin{array}{c}92.6 \\
5.6 \\
1.9\end{array}$ \\
\hline $\begin{array}{c}\text { Range } \\
\text { Mean } \pm \text { SD }\end{array}$ & \multicolumn{2}{|c|}{$\begin{array}{c}(4-28) \\
10.00 \pm 4.802\end{array}$} \\
\hline $\begin{array}{l}\text { Form friends } \\
\text { - }(4-16) \text { Low } \\
\text { - }(17-22) \text { Average } \\
\text { - }(23-28) \text { High }\end{array}$ & $\begin{array}{c}40 \\
8 \\
6\end{array}$ & $\begin{array}{l}74.1 \\
14.8 \\
11.1\end{array}$ \\
\hline $\begin{array}{c}\text { Range } \\
\text { Mean } \pm \text { SD }\end{array}$ & \multicolumn{2}{|c|}{$\begin{array}{c}(4-25) \\
14.33 \pm 5.241\end{array}$} \\
\hline $\begin{array}{l}\text { Total level of Perceived Social Support } \\
\text { - } \quad(12-48) \text { poor } \\
\text { - }(49-68) \text { Moderate } \\
\text { - }(69-84) \text { high }\end{array}$ & $\begin{array}{c}45 \\
9 \\
0\end{array}$ & $\begin{array}{c}83.3 \\
16.7 \\
0.0\end{array}$ \\
\hline $\begin{array}{c}\text { Range } \\
\text { Mean } \pm \text { SD }\end{array}$ & \multicolumn{2}{|c|}{$\begin{array}{c}(13-68) \\
35.46 \pm 11.681\end{array}$} \\
\hline
\end{tabular}


Table (4) Distribution of the studied subjects according to their total level of general health questionnaire.

\begin{tabular}{|c|c|c|}
\hline \multirow[t]{2}{*}{ General Health Questionnaire } & \multicolumn{2}{|c|}{$\begin{array}{c}\text { The studied elderly } \\
(\mathrm{n}=54)\end{array}$} \\
\hline & $\mathbf{N}$ & $\%$ \\
\hline $\begin{array}{l}\text { Somatic Symptoms } \\
\text { - }(7-19) \text { High } \\
\text { - }(20-21) \text { Average } \\
\text { - }(22-28) \text { Low }\end{array}$ & $\begin{array}{c}33 \\
12 \\
9\end{array}$ & $\begin{array}{l}61.1 \\
22.2 \\
16.7\end{array}$ \\
\hline $\begin{array}{c}\text { Range } \\
\text { Mean } \pm \text { SD }\end{array}$ & \multicolumn{2}{|c|}{$\begin{array}{c}(8-24) \\
17.26 \pm 4.443\end{array}$} \\
\hline $\begin{array}{l}\text { Anxiety and Insomnia } \\
\text { - }(7-19) \text { High } \\
\text { - }(20-21) \text { Average } \\
\text { - }(22-28) \text { Low }\end{array}$ & $\begin{array}{c}29 \\
6 \\
19\end{array}$ & $\begin{array}{l}53.7 \\
11.1 \\
35.2\end{array}$ \\
\hline $\begin{array}{c}\text { Range } \\
\text { Mean } \pm \text { SD }\end{array}$ & \multicolumn{2}{|c|}{$\begin{array}{c}(8-26) \\
17.74 \pm 6.559\end{array}$} \\
\hline $\begin{array}{l}\text { Social Dysfunction } \\
\text { - }(7-19) \text { High } \\
\text { - }(20-21) \text { Average } \\
\text { - }(22-28) \text { Low }\end{array}$ & $\begin{array}{c}18 \\
5 \\
31\end{array}$ & $\begin{array}{c}33.3 \\
9.3 \\
57.4\end{array}$ \\
\hline $\begin{array}{c}\text { Range } \\
\text { Mean } \pm \text { SD }\end{array}$ & \multicolumn{2}{|c|}{$\begin{array}{c}(9-25) \\
19.80 \pm 4.877\end{array}$} \\
\hline $\begin{array}{l}\text { Severe Depression } \\
\text { - }(7-19) \text { High } \\
\text { - }(20-21) \text { Average } \\
\text { - }(22-28) \text { Low }\end{array}$ & $\begin{array}{c}33 \\
8 \\
13\end{array}$ & $\begin{array}{l}61.1 \\
14.8 \\
24.1\end{array}$ \\
\hline $\begin{array}{c}\text { Range } \\
\text { Mean } \pm \text { SD }\end{array}$ & \multicolumn{2}{|c|}{$\begin{array}{c}(7-26) \\
17.24 \pm 6.333\end{array}$} \\
\hline $\begin{array}{l}\text { Total General Health Questionnaire } \\
\text { - }(28-78) \text { High } \\
\text { - }(79-86) \text { Moderate } \\
\text { - }(87-112) \text { Low }\end{array}$ & $\begin{array}{c}32 \\
4 \\
18\end{array}$ & $\begin{array}{c}59.3 \\
7.4 \\
33.3\end{array}$ \\
\hline $\begin{array}{c}\text { Range } \\
\text { Mean } \pm \text { SD }\end{array}$ & \multicolumn{2}{|c|}{$\begin{array}{c}(39-99) \\
72.04 \pm 18.917\end{array}$} \\
\hline
\end{tabular}




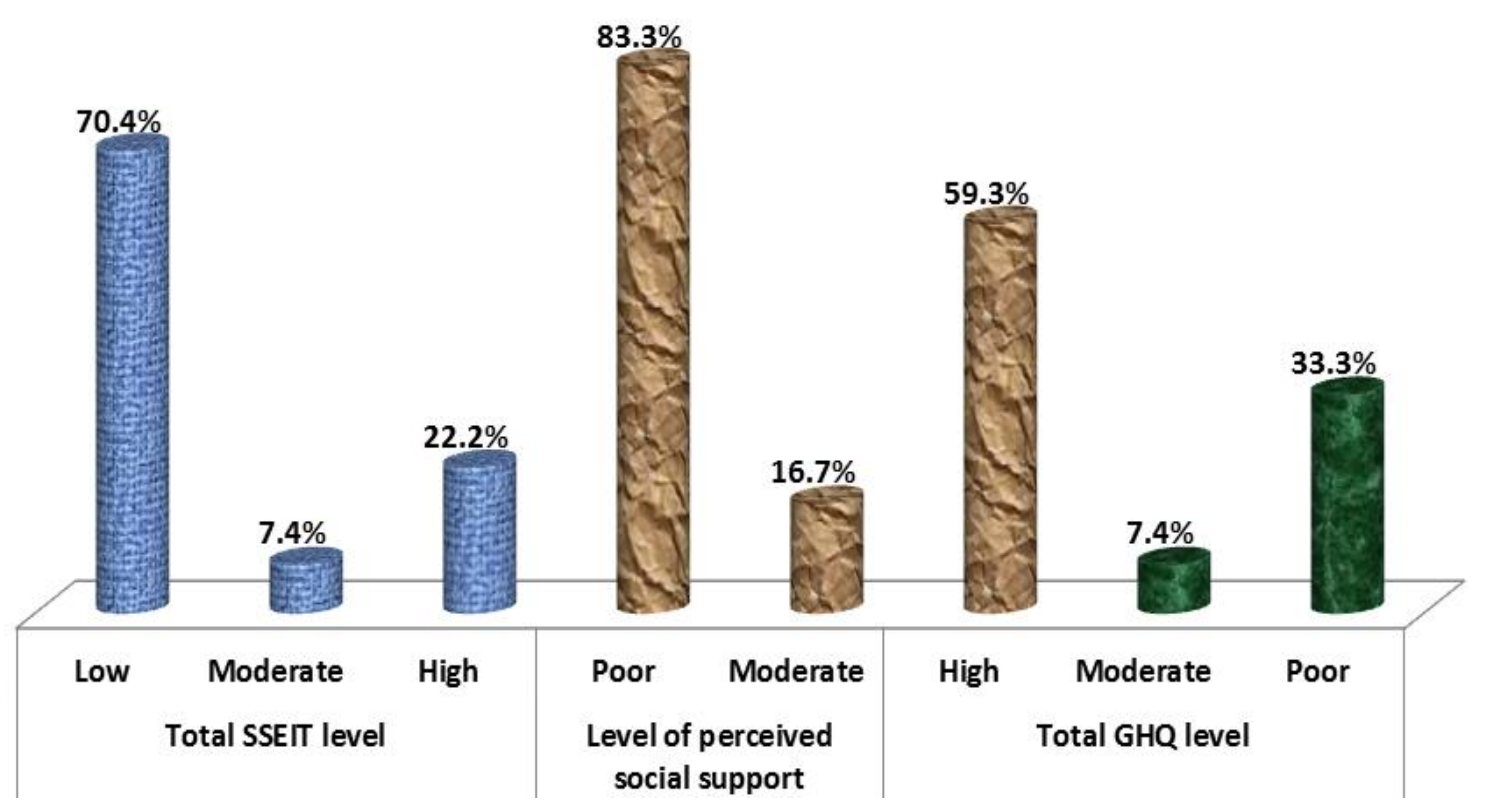

Figure: Percent distribution of both total level of Schutte Self Report Emotional Intelligence Test (SSEIT), total level of Perceived social support and total level of General Health Questionnaire (GHQ) among the studied elderly.

Table (5) Comparison and correlation between total level of Self Report Emotional Intelligence Test (SSEIT), total level of Perceived social support and total level of General Health Questionnaire (GHQ) among the studied elderly.

\begin{tabular}{|c|c|c|c|c|c|c|c|}
\hline & \multicolumn{6}{|c|}{ Total SSEIT level $(n=54)$} & \multirow{3}{*}{$\begin{array}{l}\chi^{2} \\
\mathbf{P}\end{array}$} \\
\hline & \multicolumn{2}{|c|}{$\begin{array}{c}\text { Low } \\
(n=38)\end{array}$} & \multicolumn{2}{|c|}{$\begin{array}{c}\text { Moderate } \\
(n=4)\end{array}$} & \multicolumn{2}{|c|}{$\begin{array}{c}\text { High } \\
(n=12)\end{array}$} & \\
\hline & $\mathbf{N}$ & $\%$ & $\mathbf{N}$ & $\%$ & $\mathbf{N}$ & $\%$ & \\
\hline $\begin{array}{l}\text { Total level of perceived social } \\
\text { support } \\
\text { - Poor } \\
\text { - Moderate }\end{array}$ & $\begin{array}{c}34 \\
4 \\
\end{array}$ & $\begin{array}{c}63.0 \\
7.4 \\
\end{array}$ & $\begin{array}{l}4 \\
0 \\
\end{array}$ & $\begin{array}{l}7.4 \\
0.0 \\
\end{array}$ & $\begin{array}{l}7 \\
5 \\
\end{array}$ & $\begin{array}{c}13.0 \\
9.3 \\
\end{array}$ & $\begin{array}{c}7.232 \\
0.027 *\end{array}$ \\
\hline $\mathbf{r}, \mathbf{P}$ & \multicolumn{6}{|c|}{$0.545,0.00 * *$} & \\
\hline $\begin{array}{l}\text { Total level of GHQ } \\
\text { - High } \\
\text { - Moderate } \\
\text { - Low }\end{array}$ & $\begin{array}{c}19 \\
1 \\
18\end{array}$ & $\begin{array}{c}35.2 \\
1.9 \\
33.3\end{array}$ & $\begin{array}{l}1 \\
3 \\
0\end{array}$ & $\begin{array}{l}1.9 \\
5.6 \\
0.0\end{array}$ & $\begin{array}{c}12 \\
0 \\
0\end{array}$ & $\begin{array}{c}22.2 \\
0.0 \\
0.0\end{array}$ & $\begin{array}{c}39.012 \\
0.00 *\end{array}$ \\
\hline $\mathbf{r}, \mathbf{P}$ & \multicolumn{6}{|c|}{$-0.761,0.00 * *$} & \\
\hline
\end{tabular}

* Significant at level $\mathrm{P}<0.05$

$* *$ Highly significant at level $\mathrm{P}<0.01$ 
Table (6): The relation between emotional intelligence, social support, and the mental health of elderly (general health)

\begin{tabular}{|c|c|c|c|c|c|c|c|}
\hline & \multicolumn{6}{|c|}{ Total level of GHQ $(n=54)$} & \multirow{3}{*}{$\begin{array}{l}\chi^{2} \\
\mathbf{P}\end{array}$} \\
\hline & \multicolumn{2}{|c|}{$\begin{array}{c}\text { high } \\
(n=32)\end{array}$} & \multicolumn{2}{|c|}{$\begin{array}{l}\text { Moderate } \\
(\mathrm{n}=4)\end{array}$} & \multicolumn{2}{|c|}{$\begin{array}{c}\text { Low } \\
(n=18)\end{array}$} & \\
\hline & $\mathbf{N}$ & $\%$ & $\mathbf{N}$ & $\%$ & $\mathbf{N}$ & $\%$ & \\
\hline $\begin{array}{ll} & \text { Total SSEIT level } \\
\text { - } & \text { low } \\
\text { - } & \text { Moderate } \\
\text { - } & \text { High }\end{array}$ & $\begin{array}{c}19 \\
1 \\
12\end{array}$ & $\begin{array}{c}35.2 \\
1.9 \\
22.2\end{array}$ & $\begin{array}{l}1 \\
3 \\
0\end{array}$ & $\begin{array}{l}1.9 \\
5.6 \\
0.0\end{array}$ & $\begin{array}{c}18 \\
0 \\
0\end{array}$ & $\begin{array}{c}33.3 \\
0.0 \\
0.0\end{array}$ & $\begin{array}{c}39.012 \\
0.00 *\end{array}$ \\
\hline $\mathbf{r}, \mathbf{P}$ & \multicolumn{6}{|c|}{$-0.761,0.00 * *$} & \\
\hline $\begin{array}{l}\text { Total level of perceived social } \\
\text { support } \\
\text { - } \text { Poor } \\
\text { - } \text { Moderate }\end{array}$ & $\begin{array}{c}23 \\
9\end{array}$ & $\begin{array}{l}42.6 \\
16.7\end{array}$ & $\begin{array}{l}4 \\
0\end{array}$ & $\begin{array}{l}7.4 \\
0.0\end{array}$ & $\begin{array}{c}18 \\
0\end{array}$ & $\begin{array}{c}33.3 \\
0.0\end{array}$ & $\begin{array}{c}7.425 \\
0.024 *\end{array}$ \\
\hline $\mathbf{r}, \mathbf{P}$ & \multicolumn{6}{|c|}{$-0.404,0.002 * *$} & \\
\hline
\end{tabular}


Table (7) Correlation between socio-demographic characteristics and total level of Self Report Emotional Intelligence Test (SSEIT), total level of Perceived social support and total level of General Health Questionnaire (GHQ) among the studied elderly.

\begin{tabular}{|c|c|c|c|c|c|c|}
\hline \multirow[t]{2}{*}{$\begin{array}{c}\text { Socio-demographic } \\
\text { Data }\end{array}$} & \multicolumn{2}{|c|}{$\begin{array}{l}\text { Total SSEIT } \\
\text { score }\end{array}$} & \multicolumn{2}{|c|}{$\begin{array}{c}\text { Total Perceived } \\
\text { social support } \\
\text { scores }\end{array}$} & \multicolumn{2}{|c|}{$\begin{array}{l}\text { Total GHQ } \\
\text { Score }\end{array}$} \\
\hline & $\mathbf{r}$ & $\mathbf{P}$ & $\mathbf{r}$ & $\mathbf{P}$ & $\mathbf{r}$ & $\mathbf{P}$ \\
\hline Age (in years) & -0.440 & $0.001 * *$ & -0.310 & $0.023 *$ & 0.399 & $0.003 * *$ \\
\hline $\begin{array}{l}\text { Gender } \\
\text { - Male } \\
\text { - Female }\end{array}$ & $\begin{array}{r}0.160 \\
-0.160-\end{array}$ & 0.249 & $\begin{array}{l}-0.061 \\
0.061\end{array}$ & 0.661 & $\begin{array}{l}-0.439 \\
0.439\end{array}$ & $0.001 * *$ \\
\hline $\begin{array}{ll}\text { Marital status } \\
\text { - Single } \\
\text { - Married } \\
\text { - Divorced } \\
\text { - Widow }\end{array}$ & $\begin{array}{c}-\mathbf{- 0 . 4 9 0} \\
\mathbf{0 . 3 8 8} \\
\mathbf{0 . 2 8 0} \\
-0.159\end{array}$ & $\begin{array}{c}\mathbf{0 . 0 0} * * \\
\mathbf{0 . 0 0 4} * * \\
\mathbf{0 . 0 4} * \\
0.251\end{array}$ & $\begin{array}{l}\mathbf{- 0 . 5 8 4} \\
0.251 \\
0.233 \\
0.016\end{array}$ & $\begin{array}{c}\mathbf{0 . 0 0} * * \\
0.067 \\
0.090 \\
0.909\end{array}$ & $\begin{array}{c}0.282 \\
-0.401 \\
-0.330 \\
0.344\end{array}$ & $\begin{array}{c}0.039 * \\
0.003 * * \\
0.015 * \\
0.011 *\end{array}$ \\
\hline$\frac{\text { Residence }}{\text { - Urban }}$ & $\begin{array}{c}0.062 \\
-0.062\end{array}$ & 0.657 & $\begin{array}{c}0.086 \\
-0.086\end{array}$ & 0.539 & $\begin{array}{l}-0.155 \\
0.155\end{array}$ & 0.262 \\
\hline Educational level & 0.562 & $0.00 * *$ & 0.378 & $0.005 * *$ & -0.577 & $0.00 * *$ \\
\hline $\begin{array}{ll}\underline{\text { Job }} & \\
\text { - } & \text { Retired } \\
\text { - } & \text { Don't work }\end{array}$ & $\begin{array}{c}0.399 \\
-0.399\end{array}$ & $0.003 * *$ & $\begin{array}{r}0.275 \\
-0.275\end{array}$ & $0.044 *$ & $\begin{array}{l}-0.424 \\
0.424\end{array}$ & $0.001 * *$ \\
\hline $\begin{array}{l}\text { Income } \\
\text { - Enough } \\
\text { - Not enough }\end{array}$ & $\begin{array}{c}-0.154 \\
0.154\end{array}$ & 0.265 & $\begin{array}{l}-0.007 \\
0.007\end{array}$ & 0.958 & $\begin{array}{c}0.050 \\
-0.050\end{array}$ & 0.721 \\
\hline Duration of stay (in years) & -0.327 & $0.016 *$ & -0.375 & $0.005 * *$ & 0.365 & $0.007 * *$ \\
\hline
\end{tabular}

* Significant at level $\mathrm{P}<0.05$

** Highly significant at level $\mathrm{P}<0.01$ 


\section{Discussion}

Emotional intelligence can be explained by lifelong learning and also it can be improved through practice. Young adults have few opportunities than older adults to practice emotional intelligence throughout their lives. Consequently, older adults have better understanding of emotions and use better emotional regulation strategies than younger adults ${ }^{(29)}$.

Social support has a beneficial effect on psychological well-being, it refers to an extent to which “one's perceptions of supportive behaviors from individuals in their social network ${ }^{(24)}$. Socialization influences the emotions of individuals as it provides essential skills and habits necessary for interactions in the society. It enables an individual to have selfawareness while alone and in group, motivate to move positively and handle one's own and other's emotions. Since elderly people require more emotional care, socialization helps in gaining better emotional maturity when associated with peer group ${ }^{(30)}$.

Emotional Intelligence has a significant impact on psychological, social and physical adjustment according to numerous studies. However most of those findings are related to young and middle aged samples and little is known about the association between emotional intelligence and well-being among older people. ${ }^{(31)}$ So this study was aimed to evaluate the association between the emotional intelligence, social support and mental health of institutionalized elderly.

The present study revealed that there was a significant positive relation between emotional intelligence and social support. Toyama et al 2017 confirmed this result as they stated that the results showed that emotional intelligence was directly and positively associated with social support, work environment, and creativity. This finding extends prior evidence indicating that higher emotional intelligence can improve the effectiveness of social support (32). Also it is indicated that in principle, all the dimensions of emotional intelligence construct correlate positively with the dimensions of perceived social support ${ }^{(33)}$. The present study found negative relation between emotional intelligence and mental health as if emotional intelligence were high, the mental health were low so, older adults may obtain higher emotional intelligence through learning from their life, and collected knowledge subsequently, they may be more likely to use the emotional intelligence to regulate their emotions and less perceived stress and increase their life satisfaction and 
affective well-being. This is in line with Chen Y et al 2016, as they found emotional intelligence had a positive relationship with both life satisfaction and affective well-being. Individuals who have higher emotional intelligence are also having higher life satisfaction and experience more frequent positive association to negative affect ${ }^{(29)}$. Also the results showed that between emotional intelligence and life satisfaction among the elderly of Sardasht city, there is a significant positive correlation ${ }^{(34)}$. Also

Rahmawti et al, 2017, stated that emotional intelligence has significant relation with psychological well-being. Meaning that if emotional intelligence, self-esteem, self-efficacy are high, the score of psychological well-being is also high $^{(35)}$.

The mental health of elderly was related negatively to their level of perceived social support. This is due to the elderly don't receive social support and their health is at risk if social unity is poor. Conversely, a high level of social support protects people from illnesses. Social support reduces the adverse effects of mental stress. In older adult communities, it should be said that older people who receive more social support and participate in different aspects of social life more than others, enjoy more favorable mental health. This is the same with Harandi et al 2017, who stated that perceived social support can inhibit the adverse physiological complications of diseases and increase self-care among older people. In the field of social support on patients' mental health, patients certainly find themselves in an insecure situation and seek for support that decreases their anxiety and discomfort, and thus, social support in such a situation can reduce their anxiety and discomfort ${ }^{(36)}$.

In consistent with Kafetsios 2016 ,who stated that persons with secure support models use emotional regulation strategies to minimize stress and emphasize positive emotions and those with support insecure models follow emotion regulation strategies that emphasize negative emotions and stressful situations, or tend to inhibit emotional experiences. This has obvious consequences for the link with both well-being and social support processes. Older adults have smaller support networks but the close relational networks (marital and familial relationships) are better established in later adulthood $^{(21)}$.

The results of the this study found a significant negative correlation between elderly age and their emotional intelligence which came in consistent with Atkins 
2005, who stated that younger adults who use more emotions in decision-making appear to find it more hard to control strong negative emotions and prevent them from hindering their work. However, this becomes progressively less true for older adults ${ }^{(37)}$. In contrast to diminishing associated with physical and cognitive aging, emotional aging appears to profit from age. Shifts in cognitive processing of emotional stimuli, enhanced emotional motivation and emotional competence likely contribute to improvements ${ }^{(38)}$.

In contrast to the present study Chen $\mathbf{Y}$ et al 2016, who found in their study a positive relationship between age and emotional intelligence, suggested that older adults may gain higher emotional intelligence due to lifelong learning and collected knowledge ${ }^{(29)}$.

The result showed that there was a significant positive correlation between married women elderly and their emotional intelligence, and had a negative one with their mental health. This related to women may feel less control over emotions, negative events and more responsible for emotional tone in relationships.

The present study revealed that there was a positive correlation between the study subjects' educational levels and their emotional intelligence, social support, but there was a negative correlation between the study subjects' educational levels and their mental health. This is due to the increased level of education makes the individuals more knowledgeable, more mature in their behaviors and able to accept facts, and the higher socialization and communication with others. As regards elderly job, there was a positive correlation between the study subjects 'retirement and their emotional intelligence and there was a positive correlation between the study subjects retirement and their social support, but a negative one between the study subjects retirement and their mental health, this related to those who have worked for many years are nearing retirement age and thus they are expected to be better prepared for retirement than who don't work. As working help older individuals to experience successful aging.

\section{Conclusion:}

The results found that there was a

significant positive relation between emotional intelligence and perceived social support. and there was a significant negative relation between emotional intelligence and mental health as if emotional intelligence were high, the mental health were low, also the study found a significant negative relation 
between the mental health of elderly and their level of perceived social support.

\section{Recommendations:}

Based on the results of the current study researchers recommended that:

- Establish workshops and holding seminars about emotional intelligence for elderly according to their cognitive ability from health care professionals.

- Future researches must focus on establishing the causal links among features of emotional processing, retirement and mental health concurrently and over time.

-Future researches are needed to find out exactly how older adults with higher emotional intelligence cope with the changing life circumstances to maximize their well-being.

- Development of group activities in elderly homes and social communities that will contribute to reducing isolation and loneliness in the elderly.

- Immediate need for socialization programs to elderly has to be taken care of and should be encouraged in future researches to enhance mental health and life quality in old age.

\section{References:}

1- Sweed H S. Review Articles: Population Ageing - Egypt Report. Middle East Journal of Age and
Ageing Volume 13, Issue 2 December 2016

2- The Statistical Year Book (June 2006) Central Agency For Public Mobilization and Statistics - Egypt 3-Alipour, F. and Sajjadi, H. The Role of Social Supports in Reducing Anxiety and Depression among the Elderly, Iranian Journal of Ageing, Fourth Year, Issue 11, spring 2009.

4-Egede LE, and Ellis C. Diabetes and depression: Global perspectives. Diabetes Research and Clinical Practice. 2010 Mar; 87(3):302-12

5-Moussavi S, Chatterji S, Verdes E, Tandon A, Patel V, and Ustun B. Depression, chronic diseases, and decrements in health: results from the World Health Surveys. The Lancet. 2007 Sep; 370,851-8.

6-Jongenelis K, Pot AM, Eisses AMH, Beekman ATF, Kluiter H, and Ribbe MW. Prevalence and risk indicators of depression in elderly nursing home patients: the AGED study. Journal of Affective

Disorders 2004,82(2_3):135_142

7-Boorsma M, Joling K, Dussel M, Ribbe M, Frijters D, Van Marwijk HWJ, Nijpels G, and Van Hout $H$. The incidence of depression and its risk factors in Dutch nursing homes and 
residential care homes. American Journal of Geriatric Psychiatry2012, 20 (11):932-942

8-WHO, EURO. Risk factors of ill health among older people http://www.euro .who.int/en/what-we-do/health-topics/ Life-stages/healthy-ageing/facts-andfigures/risk-factors-of-ill-healthamong-older-people Accessed 25.05. 2013.

9-McCusker J, Cole MG, Voyer P, Monette J, Champoux N, Ciampi A, $\mathrm{Vu}$ M, Dyachenko A, and Belzile E. Observed-rated depression in longterm care: frequency and risk factors. Archives of Gerontology and Geriatrics 2013. 58:332-338.

10- Santiago LM, and Mattos IE. Depressive symptoms in institutionalized older adults. Revista de Saúde Pública 2014,48 (2):216224.

11-Martins A, Ramalho N, and Morin E. A comprehensive meta-analysis of the relationship between emotional intelligence and health. Personality and Individual Differences 49(6):554564.

12-Mayer JD, Roberts RD, Barsade S. 2008. Human abilities: emotional intelligence. Annual Review of Psychology 2010, 59:507-536
13- Scheibe S, and Carstensen L. Emotional Ageing: Recent Findings and Future Trends' in the Journals of Gerontology Series B: Psychological Sciences and Social Sciences, 2009; 2:135-144.

14- Carstensen LL, Turan B, Scheibe S, Ram N, Ersner-Hershfield H, Samanez Larkin $\mathrm{G}$ et al. Emotional experience improves withage:evidence based onover 10 years of experience sampling. Psychol. Aging 2011; 26, 21-33.

15-Faralli A M. The impact of instruction on EI levels of undergraduate nursing students. Published Doctoral Dissertation, School of Education, Wilmington.University.Available:http: //proquest.umi.com.UMI Number: 3361921. (September 22, 2011)

16- Marc A. Brackett and Peter Salovey.Measuring emotional intelligence with the Mayer-SaloveryCaruso Emotional Intelligence Test (MSCEIT). Psicothema 2006. Vol. 18, supl., pp. 34-41

17- Octavio Luque-Reca, José María Augusto-Landa and Manuel PulidoMartos. Emotional intelligence and depressive symptoms in Spanish institutionalized elders: does emotional self-efficacy act as a mediator? (2016), PeerJ,1-19 
18- Hashemipour s, Askari M, Golmirzai J. Investigation of the Relationship between Emotional Intelligence and Mental Health in the ElderlyPeople of Bandar Abbas. J. Life Sci. Biomed. 3(5):335-338, 2013

19- Carole Fantini-Hauwel, and Moïra Mikolajczak, Factor Structure, Evolution, and Predictive Power of Emotional Competencies on Physical and Emotional Health in the Elderly. Journal of Aging and Health 2014, Vol. 26(6) 993- 1014

20- Hyun-Wook Kang a, Meungguk Park b, Juliane Poock, and Wallace Hernandez. The impact of perceived social support, loneliness, and physical activity on quality of life in South Korean older adults. Journal of Sport and Health Science 18 July 2016, 1-8.

21-Konstantinos Kafetsios and Georgios d. Sideridis. Attachment,Social Support and Well-being in Young and Older Adults. Journal of Health Psychology.2006, Vol, 11(6) 863-876.

22-Hadi Kooshiar, Nurizan Yahaya, Tengku Aizan Hamid, Asnarulkhadi Abu Samah, and Vajiheh Sedaghat Jou - Living Arrangement and Life Satisfaction in Older Malaysians: The Mediating Role of Social Support Function. August 2012 | Volume 7 | Issue 8 | 1-6.

23-Hege Bøen, Odd Steffen Dalgard and Espen Bjertness. The importance of social support in the associations between psychological distress and somatic health problems and socioeconomic factors among older adults living at home: a cross sectional study. Bio Med Central BMC Geriatrics 2012, 12:27.

24-Sammy K Ho and Maria P. Y. Chik. The Effects of Humor and Gender on the Relationship between Social Support and Psychological WellBeing. American Journal of Psychological Research. August 12, 2010 Volume 6, Number 1, 218-240.

25-Folstein MF, Folstein SE, and McHugh PR. “Mini-mental state". A practical method for grading the cognitive state of patients for the clinician. Journal of Psychiatric Research (1975), 12(3):189-198.

26-Schutte, N.S. and Malouff, J.M. (1998). Measuring emotional intelligence and related constructs. Levinston: Mellen Press).

27-Zimet D G, and Farely G K. The multidimensional scale of perceived social support. Journal of personality assessment, 1988, 52(1), 30-41

28-Goldberg, D. P., and Hillier, V. F. (1979). A scaled version of the General Health Questionnaire. Psychological Medicine, 9 (1), 139-145.

29- Yiwei Chen, Yisheng Peng, and Ping Fang, Emotional Intelligence Mediates the Relationship between Age and Subjective Well-Being. The International Journal of Aging and Human Development 2016, Vol. 83(2) 91-107 
30- Jesna Sivasankar, and Vidhya Ravindranadan. Effects of Socialization on Emotional Efficacy of Elderly. The International Journal of Indian Psychology, 2017, Volume 4, Issue 3, 88-95

31-Galdona N, Martínez-Taboada C, Etxeberria I, Urdaneta E, and Aldaz E. Positive aging: the relationship between emotional intelligence and psychological, social and physical wellbeing. MOJ Gerontol Ger. 2018; 3 (1):9-11

32- Toyama H, and Mauno S. Associations of Trait Emotional Intelligence with Social Support, Work Engagement, and Creativity in Japanese Eldercare Nurses. Japanese Psychological Research, 2017, Volume 59, No. 1, 14-25

33- Macula A M. Emotional Intelligence, Its Relation with Social Interaction and Perceived Social Support. European Journal of Social Sciences Education and Research, May-August 2017 Volume 4, Issue 4, 57-63

34-Sahraei M, Alipour O and, Alipour H. The Relationship between Emotional
Intelligence and Life Satisfaction. International Journal of Humanities and Culture Studies, Issue May 2016, 1720- 1724.

35- Rahmawati N R , Handarini D M, and Triyono. Relation of Emotional Intelligence, Self-esteem, Selfefficacy, and Psychological WellBeing Students of State Senior High School. Jurnal Pendidikan Humaniora Volume 5, Number 1, March 2017, pp. 40-4.

36-Harandi T F, Taghinasab $\mathrm{M} \mathrm{M}$, and Nayeri T D .The correlation of social support with mental health: A metaanalysis. Electronic Physician, September 2017, Volume: 9, Issue: 9, Pages: 5212-5222.

37-Paul W.B. Atkins .Does emotional intelligence change with age? Annual Conference, Atlanta, US April 6-7 2005, 1-27.

38-Scheibe S and. Carstensen L L. Emotional Aging: Recent Findings and Future Trends. 2010 ,Journal of Gerontology: Psychological Sciences, 65B(2), 135-144. 